\title{
A Two-Tiered Theory of Consolidation and Separation of Powers
}

\author{
David Yassky
}

Not only did the New Deal expand the permissible areas of governmental activity, it also transformed the structure of the Federal Government. President Roosevelt's innovations centralized within large bureaucracies power that previously had been dispersed among the three governmental branches. This consolidation of power fits uneasily into the constitutional framework established by the Founders.

This Note explores the jurisprudential implications of the New Deal watershed and elaborates a post-New Deal theory of allocation of governmental power. Part I begins with a discussion of the Federalist theory of separation of powers. ${ }^{1}$ For the Federalists, two conditions ensured an effective separation. First, governmental branches must be institutionally independent; each must be free from control by the others. Second, the branches must be functionally specialized; each must wield a distinct component of governmental power, so that the assent of all three is required for government action.

Until the New Deal, the Supreme Court incorporated this theory into its jurisprudence through the nondelegation doctrine, which limited the discretionary authority of administrative agencies. The Court displaced this limitation in the late 1930's and early 1940's with a series of decisions approving massive delegations of authority to the executive branch.

Contemporary separation of powers analysts dispute the meaning of the Court's repudiation of the nondelegation doctrine. Separation of powers "purists" insist on maintaining strict boundaries among the legislative, executive, and judicial functions, while "partialists" emphasize the balance of power among institutionally independent branches.

Part II presents an alternative, two-tiered theory. According to this theory, the nondelegation doctrine's demise was accompanied by the birth of a "consolidation principle" requiring concentration of the government's operational power within administrative agencies. Such consolidation must

1. In this Note, "separation of powers" refers to a dispersion of governmental authority among distinct governmental entities. See infra text accompanying notes 5-11. Contemporary analysts disagree sharply over the precise features inherent in, or required by, such dispersion, see infra Part I, Section $\mathrm{C}$, but the definition adopted here is intended to capture the common core of the various conceptions of separated powers employed by commentators and by the Court: power spread among many hands, not concentrated in one. 
be sufficient to permit activist regulation. At the same time, the traditional principle of separation of powers remains vital, though limited in scope. The "separation principle" provides the theory's second tier: The ultimate power of control over agencies must be divided among the original three branches.

Part III explains the Burger Supreme Court's two landmark separation of powers decisions ${ }^{2}$ as motivated by this two-tiered approach. The Court's rejection of the legislative vevo illustrates the consolidation principle. The veto was an attempt by Congress to interfere with the ability of administrative agencies to pursue interventionist agenda. In contrast, the Court demonstrated the continued force of the separation principle by invalidating the Gramm-Rudman-Hollings budget balancing law. ${ }^{3}$ GrammRudman-Hollings represented a congressional attempt to exclude the President from participation in ultimate control over the agencies.

Part IV, applying the two-tiered framework elaborated in earlier Parts to an issue of current importance, argues that portions of the Competition in Contracting $\mathrm{Act}^{4}$ (CICA) are unconstitutional. Like the legislative veto, GICA disrupts the consolidation of operational power within administrative agencies.

Finally, Part V offers some normative justifications for a two-tiered theory.

\section{The Challenge: The Legacy of the New Deal}

The Constitution has traditionally been read to embody a theory of separation of powers. ${ }^{5}$ In Federalist Nos. 47-51, Madison establishes the link between liberty and a struggle for power among governmental institutions: "[W]here the whole power of one department is exercised by the same hands which possess the whole power of another department, the fundamental principles of a free constitution are subverted."6 To safeguard against unconstitutional abuses of government authority, the Founders limited the Federal Government's ability to act by dividing its power among distinct branches. ${ }^{7}$ Any of the branches, by refusing to exercise its share, can prevent government action that violates the Constitution.

2. Bowsher v. Synar, 478 U.S. 714 (1986) (overturning Gramm-Rudman-Hollings deficit reduction act); INS v. Chadha, 462 U.S. 919 (1983) (declaring legislative vetoes unconstitutional).

3. Balanced Budget and Emergency Deficit Control Act of 1985, Pub. L. No. 99-177, 99 Stat. $1038,1063-93$ (current version at 2 U.S.C. $\$ \$ 901-909$ (1988)).

4. 31 U.S.C. $\$ \$ 3551-3556$ (Supp. V 1987).

5. See, e.g., Youngstown Sheet \& Tube Co. v. Sawyer, 343 U.S. 579, 635 (1952) (Jackson, J., concurring); Marbury v. Madison, 5 U.S. (1 Cranch) 137, 176 (1803); Cooper v. Telfair, 4 U.S. (4 Dall.) $14,18-19$ (1800) (opinion of Chase, J.).

6. The Federalist No. 47, at 302-03 (J. Madison) (C. Rossiter ed. 1961) (emphasis in original). This passage is quoted approvingly in the Supreme Court's most recent separation of powers decision. Mistretta v. U.S., 109 S. Ct. 647, 659 (1989).

7. Although the Constitution divides power among three branches, this Note is concerned only with the relationship between Congress and the President. Broadening the argument to include Fed- 


\section{A. Two Aspects of the Separation of Powers}

The Federalist identifies two aspects of an effective separation of powers. First, the branches must be institutionally independent so that no branch can fall under the control of the others. Federalist No. 51 sets out the structural requirements for institutional independence: "[T]he members of each [branch] should have as little agency as possible in the appointment of the members of the others. . . . [And] the members of each [branch] should be as little dependent as possible on those of the others for the emoluments annexed to their offices."

Second, the branches must be functionally specialized. Each branch must be given a meaningful share of power so that the government can act only with the willing participation of all three. The Federalist envisions that these functional assignments will be related to each branch's institutional competence, resulting in specialization and an efficient division of labor. The Congress, due to its high degree of representativeness and accountability, will best understand the "passions" of the electorate, suiting it best to articulate basic policy norms. The more removed, statesmanlike President will "reason right about the means of promoting [goals determined by the legislature]."10 The completely insulated, life-tenured Federal judiciary will "have neither FORCE nor WILL but merely judgment ...."11

\section{B. The Rise and Decline of the Nondelegation Doctrine}

From the beginning of the Republic until the New Deal period, the Supreme Court gave expression to this Federalist theory of separation of powers through the nondelegation doctrine, which held that the lawmaking power delegated by the people to Congress in the Constitution could not be redelegated by Congress to the executive. ${ }^{12}$ The Court recognized that the President would exercise discretion in administering the laws, but insisted that congressional enactments cabin this discretion with specific instructions.

This position is exemplified by J.W. Hampton, Jr. \& Co. v. United

eral courts is beyond the scope of this Note. Some implications for the judiciary are suggested infra at note 55.

8. The Federalist No. 51, at 321 (J. Madison) (C. Rossiter ed. 1961). These requirements are effected by the Constitution in the incompatibility clause, U.S. CoNST. art. I, $\$ 6, \mathrm{cl}$. 2 , the appointments clause, $i d$. art. II, $\S 2, \mathrm{cl} .2$, and the presidential and judicial compensation clauses, id. art. II, $\S$ 1, cl. 7 ; id. art. III, $\$ 1$.

9. The Feveralist No. 49, at 317 (J. Madison) (C. Rossiter ed. 1961) (emphasis omitted).

10. Id. No. 71 , at 432 (A. Hamilton) (emphasis in original).

11. Id. No. 78 , at 465 (A. Hamilton) (emphasis in original).

12. See generally G. Stone, L. Seidman, C. Sunstein \& M. Tushnet, Constitutional LAw 365-71 (1986) (discussing rise and fall of nondelegation doctrine). For early statements of the nondelegation doctrine, see Wayman v. Southard, 23 U.S. (10 Wheat.) 1, 42-43 (1825); Cargo of the Brig Aurora v. United States, 11 U.S. (7 Cranch) 382, 388 (1813) (permitting embargo conditioned upon presidential findings); see also cases cited infra at note 17. 
States. ${ }^{13}$ Hampton upheld a "flexible tariff" provision authorizing the President to adjust import duties to "equalize . . . differences in costs of production in the United States and the principal competing country."14 The Court ruled that this provision did not constitute a "delegation to the President of the legislative power"15 because it established an "intelligible principle" for the executive to obey ${ }^{16}$ By forbidding the President from legislating, the nondelegation doctrine both preserved the branches' functional specialization and prevented centralization of power in the executive. ${ }^{17}$

The Court's reliance on the nondelegation doctrine reached a crescendo in the early New Deal period, as President Roosevelt's innovations accelerated the concentration of Federal Government power within the executive branch. Faced with these rapid changes, the Court in Panama Refining Co. v. Ryan ${ }^{18}$ and in A.L.A. Schechter Poultry Corp. v. United States $^{18}$ struck down the New Deal's centerpiece National Industrial Recovery Act, ${ }^{20}$ declaring: "The Congress is not permitted to abdicate or to transfer to others the essential legislative functions with which it is . . vested." 21

After the election of 1936, however, the Supreme Court abruptly reversed ground, ending its opposition to the New Deal and permitting large grants of power to the executive. ${ }^{22}$ In NLRB v. Jones $\mathcal{E}$ Laughlin

\footnotetext{
13. 276 U.S. 394 (1928).

14. Tariff Act of 1922 , ch. 356,42 Stat. 858 at $941-42, \S 315(a)$.

15. Hampton, 276 U.S. at 404.

16. Id. at 409.

17. Despite its repeated invocations of the nondelegation doctrine, the Court did not actually strike down a congressional delegation until the New Deal. See N.Y. Cent. Sec. Corp. v. United States, 287 U.S. 12, 24-26 (1932) (upholding ICC authority to approve mergers); Tagg Bros. \& Moorhead v. United States, 280 U.S. 420, 436-39 (1930) (upholding authority of Secretary of Agriculture to prescribe industry-wide tariffs); United States v. Grimaud, 220 U.S. 506, 516-21 (1911) (permitting Agriculture Secretary to regulate forest preserves); Buttfield v. Stranahan, 192 U.S. 470, 496-97 (1904) (permitting Treasury Secretary to issue standards); Field v. Clark, 143 U.S. 649, 692 (1892) (permitting import duties conditioned upon presidential finding). Perhaps one reading of this history would see the nondelegation doctrine as practically meaningless. But this would fail to credit the Court's efforts to accommodate the incipient national administrative state within the Federalist constitutional framework-until the New Deal expansion rendered the Court's delicate accommodation untenable. For a description of the development of Federal administrative capabilities during the late nineteenth and early twentieth centuries, see S. SKowroneK, Building a NEW AMERICAN STATE 47-68 (1982).
}

18. 293 U.S. 388 (1935).

19. 295 U.S. 495 (1935).

20. National Industrial Recovery Act, ch. 90, 48 Stat. 195 (1933) (omitted from United States Code due to unconstitutionality).

21. Schechter, 295 U.S. at 529.

22. Professor Ackerman has argued that the election of 1936 effected a constitutional amendment. Ackerman, Constitutional Politics/Constitutional Law, 99 YALE L.J. (forthcoming 1989); Ackerman, The Storrs Lectures: Discovering the Constitution, 93 YALE L.J. 1013, 1051-57 (1984). My argument in this Note does not require acceptance of Professor Ackerman's thesis, although I find in it much to credit. Whether the Court recognized in 1937 that We the People had authorized an activist state, or whether the Justices were simply persuaded by the New Dealers' strenuous attacks on the philosophical underpinnings of the early Hughes Court's laissez-faire regime, I claim only that the Court's separation of powers jurisprudence experienced a major shift in the 1930's and that later 
Steel Corp.,${ }^{23}$ the Court, without mentioning the nondelegation doctrine, upheld Congress' establishment of a National Labor Relations Board with complete power to regulate labor unions and labor-management relations. ${ }^{24}$ Even Justice McReynolds' dissent takes for granted that the delegation of authority is legitimate: "The precise question for us to determine is whether . . . Congress by statute [could] direct what the Board has ordered."25

By 1944, the Court in Yakus v. United States ${ }^{26}$ was willing to permit an essentially standardless delegation. Yakus approved a Price Administrator with the authority to set commodity prices and rents that were "fair and equitable" and that would "effectuate . . . purposes" including stabilizing prices, preventing speculation, assisting the defense effort, and protecting people with fixed incomes. ${ }^{27}$ The Yakus Court contented itself with the observation that Congress had "specified the basic conditions of fact" necessitating the delegation. ${ }^{28}$ While the Court never acknowledged its repudiation of Schechter/Panama reasoning, it drained the nondelegation doctrine of useful meaning. ${ }^{29}$

\section{G. The Contemporary Separation of Powers Debate}

In repudiating the nondelegation doctrine, the Supreme Court approved centralization of policy-making authority. The task of giving constitutional meaning to this monumental event has raised difficulties for contemporary separation of powers analysts, who have identified two approaches: a pure-separation approach emphasizing "the constitutional effort to allocate different sorts of power among three [different] government entities" and a partial-separation approach focusing on the "constitutional effort to ... guard against the usurpation of authority by any one branch." 30

decisions have attempted to integrate this shift into the pre-existing framework.

23. 301 U.S. 1 (1937).

24. National Labor Relations Act, ch. 372, 49 Stat. 449 (1935) (codified as amended at 29 U.S.C. $\$ \$ 151-169$ (1982 \& Supp. V 1987)).

25. Labor Board Cases, 301 U.S. 1, 93 (1937) (McReynolds, J., dissenting).

26. 321 U.S. 414 (1944).

27. Emergency Price Control Act of 1942 , ch. 26,56 Stat. 23 at $23-25, \S \S 1$ (a), 2(a).

28. Yakus, 321 U.S. at 424; see also Lichter v. United States, 334 U.S. 742, 778 (1948) ("A constitutional power implies a power of delegation of authority under it sufficient to effect its purposes.") (emphasis in original); United States v. Rock-Royal Coop., 307 U.S. 533, 574 (1939) (congressional delegations "need specify only so far as is reasonably practicable"); Currin v. Wallace, 306 U.S. 1, 17 (1939) (delegation to Agriculture Secretary of power to establish standards is "plainly appropriate").

29. The Court has tacitly acknowledged the New Deal transformation most recently in Mistretta v. United States, 109 S. Ct. 647, 655 (1989) (footnotes and citations omitted): "After invalidating in 1935 two statutes as excessive delegations, see A.L.A. Schechter Poultry Corp. v. United States and Panama Refining Co. v. Ryan, we have upheld, again without deviation, Congress' ability to delegate power under broad standards." The Mistretta Court, relying primarily on Yakus, rejected a nondelegation doctrine challenge to a Sentencing Commission empowered to establish sentences for most Federal crimes. Id. at 654-58. See infra note 84.

30. G. Stone, L. SeIdman, C. Sunstein \& M. Tushnet, supra note 12, at 342 (distinguishing 
Scholars in the partial-separation camp see the demise of the nondelegation doctrine-and the concomitant concentration of power within administrative agencies-as necessitating abandonment of traditional separation of powers insistence on functional specialization. ${ }^{31}$ By promulgating rules, implementing policies, and making case-by-case determinations, these agencies combine all three facets of governance. Partialist commentators contend that modern separation of powers theory cannot, consistent with this reality, contain a strict requirement of functional specialization.

Instead, the partial-separation approach develops the insight that the fundamental goal of separated powers is to give each branch a veto over government action. This objective requires only that government power be divided among independent branches. Rather than policing the branches' functional specialization, the Court's role is limited to safeguarding the basic structural requisites for each branch's independence and to ensuring that none is wholly excluded from the governing process. ${ }^{32}$ Partialist scholars thus support measures to give Congress some control over the executive agencies; they deem it more important to counter the threat of congressional marginalization posed by the agencies' power than to maintain a rigid boundary between the legislative and executive functions. ${ }^{33}$

The pure-separation approach, professing fidelity to the Founders' vision, ${ }^{34}$ rejects this partialist encroachment on functional purity: "[T]he Constitution makes clear that the executive and judicial branches have no legislative power; that no part of the judicial power is conferred on the legislature or the executive; and that only the executive branch can exer-

"separation of powers" approach from "checks and balances" approach); $f f$ M. VILE, ConSTrTUTIONALISM AND THE SEPARATION OF PowERs 13-20 (1967) (distinguishing between pure and partial approaches); Sargentich, The Contemporary Debate About Legislative-Executive Separation of Powers, 72 Cornell L. Rev. 430, 434-36 (1987) (distinguishing separation of powers from checks and balances); Strauss, Formal and Functional Approaches to Separation-of-Powers Questions-A Foolish Inconsistency?, 72 CoRNel.L L. REv. 488, 489 (1987) (distinguishing formal and functional approaches); Sunstein, Constitutionalism After the New Deal, 101 HARv. L. REv. 421, 493-96 (1987) (same).

31. See, e.g., G. Stone, L. Seidman, C. Sunstein \& M. Tushnet, supra note 12, at 342 ; Strauss, The Place of Agencies in Government: Separation of Powers and the Fourth Branch, 84 Colum. L. REv. 573, 578-79 (1984).

32. Although partialists often refer to the ineradicable bedrock of institutional independence possessed by each branch as "core functions," this terminology is somewhat misleading. The logical essence of the partialist position only requires that there be bedrock powers, not that these powers have any particular functional cast. The three branches might be called the Dodgers, the Giants and the Yankees as well as the legislature, the executive and the judiciary, provided that each retains a veto over government action.

33. See, e.g., Strauss, Was There a Baby in the Bathwater? A Comment on the Supreme Court's Legislative Veto Decision, 1983 Duke L.J. 789, 812-16.

34. See, e.g., Burns \& Markman, Understanding Separation of Powers, 7 Pace L. REv. 575, 578 (1987); Carter, From Sick Chicken to Synar: The Evolution and Subseguent De-Evolution of the Separation of Powers, 1987 B.Y.U. L. REv. 719, 720. Detractors of the pure approach also characterize it as originalist. See INS v. Chadha, 462 U.S. 919, 967-1003 (1983) (White, J., dissenting); Tribe, The Legislative Veto Decision: A Law By Any Other Name?, 21 Harv. J. on Legrs. 1, 3 (1984). 
cise executive power." ${ }^{35}$ The pure-separation approach would therefore resist congressional attempts to exercise control over administrative agencies, even at the risk of executive domination. ${ }^{36}$ Purist scholars either ignore the broad authority possessed by agencies, implicitly denying that this authority contravenes the separation of powers, ${ }^{37}$ or call for a revival of the nondelegation doctrine to eliminate agency lawmaking. ${ }^{38}$ While most academic commentators favor a partial-separation approach, ${ }^{39}$ much recent Supreme Court jurisprudence has been read as exemplifying a pure-separation approach. ${ }^{40}$

\section{The Solution: A Two-Tiered Theory of Allocation of POWER}

Framing debate between the poles of the pure-separation and partialseparation approaches compels a choice between functional specialization and institutional independence. The pure-separation approach seeks to preserve specialization but countenances centralization of power in a single branch-the executive. The partial-separation approach permits a countervailing increase in congressional power, but only by accepting a mixture of functions. Both approaches, then, interpret Jones \& Laughlin and Yakus as compromising the Federalist principle of separation of powers by requiring retreat from one of its two aspects.

I propose instead a two-tiered theory of allocation of power, with one set of rules applicable to exercises of power by administrative agencies and another set of rules applicable to interactions among the original three branches. This theory is motivated by two perceptions: first, that the demise of the nondelegation doctrine constituted a positive affirmation of the activist state; and, second, that this affirmation must be understood in the context of an overarching system of separated powers.

\section{A. The Principle of Consolidation of Power}

In a way, my reading of Jones $\mathbb{E}$ Laughlin and Yakus goes further than either the pure-separation approach or the partial-separation approach: Not only did these decisions run directly contrary to the Federalist principle of separation, but they were animated instead by a principle of consolidation. This consolidation principle requires, rather than merely

35. Burns \& Markman, supra note 34, at 579.

36. See, e.g., Currie, The Distribution of Powers After Bowsher, 1986 Sup. Cr. REv. 19, 32-34.

37. See, e.g., id.; Burns \& Markman, supra note 34.

38. See Gewirtz, The Courts, Congress and Executive Policy-Making: Notes on Three Doctrines, 40 Law \& Contemp. Probs. 46, 49-65 (Summer, 1976).

39. See, e.g., L. Tribe, American Constitutional Law 18-20 (2d ed. 1988); Bruff, On the Constitutional Status of the Administrative Agencies, 36 AM. U.L. Rev. 491, 493-95 (1987); Strauss, supra note 30, at 492; Sunstein, supra note 30, at 496. But see, e.g., Carter, supra note 34; Currie, supra note 36.

40. See infra notes 51-53 and accompanying text. 
accepts, government agencies that combine legislative, executive, and judicial functions within a single institution.

In this view, the Court's precipitous shift in 1937 signaled the constitutionalization of an activist regulatory state. The nondelegation doctrine was inconsistent with this new regime, and so the Court abandoned it. But the Court's rejection of pre-New Deal separation of powers jurisprudence did not leave a void, permitting Congress and the President to array the Federal Government as they saw fit. Rather, the New Deal challenged the Court to elaborate a positive vision of a constitutional order based on government activism. ${ }^{41}$

The keystone of this vision is the perception that an activist national government cannot be encumbered by multi-branch checks and balances. Separated powers, by affording each of three branches the opportunity to prevent government action, effectively inhibit regulation. The New Deal rejected such constraints, introducing an activist imperative into the Federal Government's structure. This imperative demands that administrative agencies be free to regulate without having to wait for agreement among the three branches-without, that is, the restraints of separated powers. While the Federalist principle of separation of powers forbids exclusion of any of the three branches from the policy-making process, the New Deal principle of consolidation of power mandates that this process be the exclusive domain of a single entity. ${ }^{42}$ The effect of the New Deal is that government inaction is no longer the privileged baseline condition from which any departure requires the agreement of all three branches; instead, intervention is the default position.

\section{B. Operational Power and Ultimate Power}

At the same time, my interpretation of the demise of the nondelegation doctrine finds a greater continuity with Federalist ideals than does either the purist or the partialist approach. In recognizing the force of the consolidation principle, I do not claim that the Court has superseded, or even compromised, the Federalist principle of separation of powers. Rather, the Court has resolved the apparent conflict between these two principles through a two-tiered theory of allocation of power.

41. There may indeed have been such a void for a period of time following the Court's New Deal reversal. For example, Justice Jackson's "twilight zone" formulation is concerned exclusively with the relative powers of Congress and of the President; Jackson appears to assume that there are no constitutional limits to the ability of the two branches jointly to structure government action. See Youngstown Sheet \& Tube Co. v. Sawyer, 343 U.S. 579, 635-38 (1952) (Jackson, J., concurring). I conjecture that in the immediate aftermath of Roosevelt's sweeping victories, it may have seemed to the Justices that the lesson of the New Deal was that limits on Federal Government structure-enforced separation between the legislative and executive powers-had been eradicated. Only over time has the Court been able to discern the New Deal's positive dimension, and accordingly to construct new, activist requirements. B.

42. Not all governmental power must be consolidated, as we shall see. See infra Part II, Section 
To reconcile the opposing principles, the Court has had to bifurcate its view of government power ${ }^{43}$ into two distinct spheres of application, one employing the principle of separation and one requiring the consolidation principle. Bifurcation limits the scope of both the consolidation principle and the separation principle, enabling a jurisprudence that accommodates both.

In deciding which principle to apply, the guiding postulate must be that the consolidation principle is to apply only to operational power-that amount of the government's power required by activist agencies to formulate and implement policy. This requirement links application of the consolidation principle directly to the New Deal goal of facilitating government activism. The separation principle requires division between Congress and the President of the ultimate power to govern the agencies - to decide how they are to be structured, who is to staff them, what areas they are to regulate, and how resources are to be allocated among them. ${ }^{44}$

In sharpening the distinction between operational and ultimate power, care must be taken not simply to equate operational power with the work of the administrative agencies. Such a definition would be circular. ${ }^{45}$ Nor can operational power be defined functionally. Dissolving power into functional components is useful only if it is to be shared by differentiated actors. ${ }^{48}$ But administrative agencies must be self-sufficient; they must be able to exercise all of the functional aspects of power.

These two dead ends point out that the essential characteristic of the authority possessed by administrative agencies has nothing to do with how the agencies are structured and nothing to do with the forms by which they exercise authority, but it has everything to do with the power relationship between the agencies and the private actors they regulate. This suggests a definition of operational power based on the object of power: Operational power includes all exercises of power aimed directly at private individuals or groups, while ultimate power is exercised over other governmental actors. ${ }^{47}$ This distinction gives effect to the consolidation

43. By "exercises of power" I mean to refer to any authoritative statement as to the orientation of the state or of state actors towards private individuals or groups, other state actors or entities, or foreign persons or entities.

44. Compare this formulation with M. VILE, supra note 30, at 329-39 (describing tension between coordination and control in government). See also Strauss, supra note 31 (three original branches share control of administrative agencies).

45. If the consolidation principle requires operational power to be centralized within executive agencies, and operational power is defined simply as the work of those agencies, then the consolidation principle will, by definition, always be satisfied. For the consolidation principle to be meaningful, operational power must be defined without reference to the institutional structures on which the principle acts.

46. Indeed, legislation (or execution or adjudication) is a sensible concept only in relation to other modes of exercising power.

47. Although limited to the sphere of ultimate power, within that sphere the separation principle can be retained in its full vigor by dividing ultimate power among branches that are both institution- 
principle, but not at the expense of separated powers; the point at which the separation principle obtains has simply been pushed back so that not all policy-making authority need be divided. Control of the bureaucratic apparatus, but not particular administrative initiatives, requires agreement among the original branches.

The distinction between operational power and ultimate power is best elaborated through case law, and my discussion in the following Part III may provide some illumination. ${ }^{48}$ But a potentially confusing issue should be clarified at the outset: One component of ultimate power is the ability to determine what areas of society are to be regulated. The consolidation principle does not guarantee the jurisdiction of any particular administrative agency, nor the satisfaction of any particular societal need or interest. So defined, the distinction between operational power and ultimate power may appear to collapse: The ability to set regulatory goals, one might think, surely subsumes the ability to structure the policy-making process for accomplishing those goals-the ability, in other words, to draw the line between operational and ultimate power. I insist, however, that the branches do not have a free hand in structuring policy-making processes. The consolidation principle constrains: If an area is to be regulated, power to regulate autonomously must be centralized within the agencies. Congress and the President may not agree to divide operational power. This, I now argue, is the lesson of INS v. Chadha. ${ }^{49}$

\section{Evidence for a Two-Tiered Theory: The Burger Court DECISIONS}

Twice near the end of its tenure, the Burger Supreme Court struck down important legislation purporting to allocate power between Congress and the President. ${ }^{50}$ Because the language of these opinions emphasizes rigid boundaries between the executive and legislative branches, they have been received by both purists ${ }^{51}$ and partialists ${ }^{52}$ as evidencing a pur-

ally independent and functionally specialized. Thus Congress should oversee the agencies in a way that is distinctly legislative, the President should exercise her share of ultimate authority in a way that is distinctly executive, and Federal courts should review agency decisions in a way that is distinctly judicial. For a suggestion as to what these restrictions might look like in the case of Congress, see J. Ely, Democracy and Distrust: A Theory of Judicial Review 90 (1980) ("Ex Post Facto and Bill of Attainder Clauses . . . [are] separation of powers provisions, enjoining the legislature to act prospectively and by general rule").

48. See infra text accompanying note 60 (power to deport aliens is operational power); text accompanying note 83 (power to allocate funding among agencies is ultimate power); note 71 (power to restructure administrative agencies and power to allocate funding are ultimate powers).

49. 462 U.S. 919 (1983) (declaring legislative vetoes unconstitutional).

50. Id.; Bowsher v. Synar, 478 U.S. 714 (1986) (overturning Gramm-Rudman-Hollings deficit reduction act).

51. See, e.g., Burns \& Markman, supra note 34, at 590-93; Carter, supra note 34, at 731-36; Currie, supra note 36 , at 30,33 .

52. See, e.g., Bowsher, 478 U.S. at 776 (White, J., dissenting); Chadha, 462 U.S. at 967-1003 (White, J., dissenting); Stewart, Beyond Delegation Doctrine, 36 AM. U.L. Rev. 323, 323 (1987); Strauss, supra note 33, at 794-80; Sunstein, supra note 30, at 493; Tribe, supra note 34, at 1-3. 
ist, "distinctly non-New Deal"\$3 vision of separated powers. Actually, these cases provide strong support for the hypothesis that the Court has responded to the New Deal by creating a two-tiered doctrine of allocation of power. ${ }^{54}$ The Court in INS v. Chadha applied the consolidation principle to strike down an attempt by Congress to exercise operational power. In contrast, Bowsher $v$. Synar displays the continued vitality of the separation principle-limited in scope to cases involving ultimate power-by ensuring that Congress shares with the President the power to allocate funding among agencies (see Figure 1)..$^{\text {s5 }}$

\section{Figure 1}

\begin{tabular}{lll} 
Case & $\begin{array}{c}\text { Type of Power } \\
\text { at Stake }\end{array}$ & \multicolumn{1}{c}{$\begin{array}{c}\text { Principle Employed } \\
\text { by Court }\end{array}$} \\
\cline { 2 - 2 } Chadha & operational & consolidation \\
Bowsher & ultimate & separation
\end{tabular}

\section{A. The Legislative Veto Case}

In Chadha, the Court struck down a portion of the Immigration and Nationality Act (INA). ${ }^{56}$ The INA grants to the Attorney General (the Immigration and Naturalization Service (INS) is part of the Justice Department) discretion to suspend deportation of an otherwise deportable alien, ${ }^{57}$ but a "legislative veto" provision enabled either house of Con-

53. Aman, Intraduction, 72 CORNELl L. REv. 421, 426 (1987).

54. I cannot plausibly suggest that any of the Justices joining the majorities in Chadha and Bowsher, much less the author of the majority opinions, explicitly subscribes to the two-tiered theory of allocation of power that I have outlined. Indeed, the originalist rhetoric of the opinions gives no indication of a principle of consolidation, or of a distinction between operational and ultimate power. Nonetheless, it is part of my argument that the intuitions of the Justices who decided these cases were shaped importantly by a recognition of the two-tiered structure of the post-New Deal Federal Government. This claim is corollary to my contention that the Court's turn-around in 1937 announced a new and enduring constitutional principle. My argument is not simply that Chadha and Bowsher are consistent with the two-tiered theory, but that these decisions were compelled by the Court's effort to integrate the New Deal's constitutionalization of government activism into the preexisting framework of separated powers.

55. Two other Burger Court separation of powers decisions are worthy of mention. Both concern the authority of officials outside the Federal judiciary (so-called "legislative courts") to adjudicate individual disputes. Commodity Futures Trading Comm'n v. Schor, 478 U.S. 833 (1986) (permitting CFTC to decide state-law counterclaims); Northern Pipeline Constr. Co. v. Marathon Pipe Line Co., 458 U.S. 50 (1982) (declaring bankruptcy courts unconstitutional). Without attempting a full-scale application of the two-tiered approach to the judiciary, I suggest that these decisions must be understood as differentiating between operational power and ultimate power. Part of the operational power indispensible to administrative agencies is the ability to apply law to individual cases in the first instance. The CFTC's claim to this power as necessary to its regulatory program is vindicated in Schor. At the same time, the ability of Article III courts to exercise the ultimate power to adjudicate the constitutionality of agency structure and procedures cannot be eviscerated; this concern drove the decision in Northern Pipeline.

56. Immigration and Nationality Act, ch. 477, 66 Stat. 166 (1952) (codified as amended at 8 U.S.C. $\$ \$ 1101-1525$ (1988)).

57. 8 U.S.C. $\$ 1254$ (a) (1988). Congress directed the Attorney General to suspend deportation in 
gress, by majority vote, to overrule such a suspension. ${ }^{38}$ The Court invalidated this provision as violating the bicameral passage and presentment requirements of Article I of the Constitution. ${ }^{59}$

Commentators err by accepting at face value the purist rhetoric of Chief Justice Burger's majority opinion. In fact, Chadha is not at all concerned with the separation of powers; it is driven instead by the consolidation principle. The legislative veto is unconstitutional because it enables Congress to exercise some of the operational power that should be centralized within the INS.

The deportation power qualifies as operational under the two-tiered definition. It is intimately bound up with the day-to-day process of interaction between the INS and the private individuals it governs. More generally, discretionary power over deportation is essential to the INS' ability to regulate citizenship. Any INS effort to carry out immigration policy on its own would be completely hamstrung if the INS were forced to gain congressional assent to each use of the only tool at its disposal-deportation. To avoid this danger, the Court recognized, the deportation power must be consolidated within the INS.

My rebuttal to the conventional misreading of Chadha is twofold. First, I want to debunk the surface illusion that the case is only about procedural constraints on Congressional action. ${ }^{60}$ Chadha-indeed any decision about how Congress can exercise its power-necessarily depends on an analysis of the limits of Congress' power in relation to the executive branch. Second, I want to show that the Court's implicit analysis of these limits cannot be understood as protecting the separation between Congress and the President, but only as guaranteeing consolidation of operational power within an administrative agency.

\section{Explaining the Chadha Opinion}

The Chadha decision appears to rest on its definition of legislative action. Writing for the Court, Chief Justice Burger quotes extensively from Article I and from The Federalist to establish that all legislative acts must be passed by both houses of Congress and be presented to the President for signature or veto. ${ }^{61}$ But while legislation certainly requires bicameral

\footnotetext{
cases of "extreme hardship" or "extremely unusual hardship." Id.

58. Immigration and Nationality Act, Pub. L. No. 82-414, § 244, 66 Stat. 163, 214-17 (1952), repealed by Immigration Technical Corrections Act of 1988, Pub. L. No. 100-525, \$2(q)(1)(b), 1988 U.S. CODE CONG. \& ADMin. News (102 Stat.) 2609, 2614.

59. U.S. Consr. art. I, § 7, cl. 2: "Every Bill which shall have passed the House of Representatives and the Senate, shall, before it becomes a Law, be presented to the President ...."

60. My analysis of Chadha draws on the following articles: Elliott, INS v. Chadha: The Administrative Constitution, the Constitution and the Legislative Veto, 1983 Sur. CT. REv. 125, 131-44; Sargentich, supra note 30, at 468-77; Strauss, supra note 33, at 794-801; Tribe, supra note 34, at 3-18.

61. See Chadha, 462 U.S. at $945-51$.
} 
passage and presentment, the Court's argument begs the real question of whether the veto is indeed legislation. ${ }^{62}$ In dissent, Justice White offers an alternative characterization. He portrays the veto resolution not as an independent legislative event but as part of a comprehensive process that begins with Congress' delegation, continues through the INS' administrative determinations, and is completed (case-by-case) by either Congress' veto or its tacit consent. ${ }^{63}$

Choosing between these competing characterizations requires an inquiry into the veto device's consequences for the allocation of power between Congress and the President. This inquiry is absent from the Chadha opinion. Instead, Burger provides a simplistic definition of legislation that is both overbroad and circular: The veto resolution is legislation because it "alter[s] the legal rights, duties, and relations of persons." This formulation is overbroad because executive rulemaking, agency determinations, and judicial decisions all alter legal rights, yet none comply with Article I requirements for legislation. More fatal, as Professor Elliott observes, the "legislative veto 'alters legal rights' . . . only because the Court chooses to characterize its effect that way." able alien's legal right to a suspension as perfecting prior to congressional failure to veto, Burger assumes his conclusion.

Ultimately, then, Burger's characterization of the veto as legislative rests on his statement that "[w]hen any Branch acts, it is presumptively exercising the power the Constitution has delegated to it." ${ }^{\text {"B }}$ Burger's circular definition of legislation makes this presumption dispositive. As Professor Sargentich notes: "[T]his analysis appears to collapse the concepts of the action involved (lawmaking) and the actor undertaking the action (Congress)." ${ }^{67}$ The true focus of Chadha is not the definitional boundaries of the legislative function, but the limits imposed by Congress' relationship to the executive branch.

\section{Chadha as an Application of the Consolidation Principle}

Commentators who reach this point, realizing that Chadha rests on an unstated analysis of the appropriate allocation of power between the legislature and the executive, assume that the holding is motivated by a concern to further the separation between the legislative and executive pow-

62. Burger concedes that not every congressional action is to be considered legislation. Id. at 952 . The language of Article I itself contemplates non-legislative congressional action: "Every Order, Resolution, or Vote to Which the Concurrence of the Senate and House of Representatives may be necessary . . . U.S. ConsT. art. I, \& 7, cl. 3.

63. Chadha, 462 U.S. at 994-95 (White, J., dissenting).

64. Id, at 952 .

65. Elliott, supra note 60, at 134; see also Sargentich, supra note 30 , at 471 (demonstrating circularity of Chadha's definition of legislation); Strauss, supra note 33, at 796 (same).

66. Chadha, 462 U.S. at 951.

67. Sargentich, supra note 30 , at 472 . 
ers. ${ }^{68}$ But the internal logic of this putative Chadha position simply does not make sense. The legislative veto does not contravene Federalist division-of-power interests; rather, it furthers them. Most administrative agencies, including the INS, are controlled by the President. ${ }^{68}$ Denying Congress the legislative veto ensures that policy-making will be dominated by the President. In the context of a government composed primarily of large executive bureaucracies, the legislative veto would result in an uneasy sharing of power by Congress and the President-exactly the Federalist prescription.

To put this point another way, Chadha demonstrates that the Court has bifurcated its understanding of governmental power. Justice White's dissent points out that, far from being "a sword with which Congress has struck out to aggrandize itself at the expense of the other branches," the legislative veto merely allows Congress to retain some control over policymaking. ${ }^{70}$ If the Court held a single-tiered view of governmental power, Justice White would surely be correct; the veto enables some redress for what is otherwise an imbalance of power in favor of the executive.

The Court's two-tiered approach, however, means that not every power imbalance is to be redressed. Specifically, operational power wielded by administrative agencies need not be dispersed; indeed, it must be consolidated. The Court will step in to ensure division only when the ultimate power of control over these agencies threatens to become concentrated. Because the Court in Chadha is concerned with operational power, not ultimate power, it applies the principle of consolidation. ${ }^{71}$

68. See, e.g., Burns \& Markman, supra note 34, at 590-93; Carter, supra note 34, at 739; Elliott, supra note 60, at 146-47; Sargentich, supra note 30, at 469-70; Tribe, supra note 34, at 17.

69. The two-tiered theory does not demand that agencies be located in the executive branch. The consolidation principle requires only that operational power be centralized within administrative agencies, not that it be wholly under presidential control. Congress has some flexibility in structuring the precise relationship between the agencies and the President. Agency location can, however, present separation-principle problems. See infra note 84.

70. Chadha, 462 U.S. at 974 (White, J., dissenting).

71. Chadha was written too broadly, however, because not all legislative veto structures would be unconstitutional. Some exercises of government power-those involving ultimate power-are properly made contingent upon interbranch agreement (under the separation principle). Because the consolidation principle applies only when operational power is at stake, the legislative veto is unconstitutional only when used to exercise operational power; a veto exercised in an area of ultimate power-for example, the budget power or the power to restructure administrative agencies-would be valid. $C f$. Strauss, supra note 33, at 805-17 (distinguishing between constitutional "political" vetoes and unconstitutional "regulatory" vetoes).

There is some indication that lower Federal courts have appreciated this distinction in post-Chadha legislative veto cases. One issue in Chadha was the severability of the legislative veto. The Court could have used the unconstitutionality of the veto to invalidate the Justice Department's discretionary power over deportation. Instead, the Court chose to sever the veto provision from the remainder of the INA, leaving intact its broad delegation of authority to the Justice Department. Chadha, 462 U.S. at 931-35. But see id. at 1013-16 (Rehnquist, J., dissenting on ground that veto not severable). This result is compelled by the consolidation principle-because the deportation power is operational and must be left with the INS-and the general rule has been that vetoes are severable. See Alaska Airlines v. Brock, 480 U.S. 678 (1987) (severing veto in duty-to-hire statute).

This rule makes sense in most legislative veto cases, because the power at issue is operational and must be given to administrative agencies. But where the power at issue is ultimate power, severing a 
The premise underlying Chadha-that the power to suspend deportations is operational, and therefore subject to the consolidation principle-becomes evident in Burger's response to a nondelegation doctrine challenge to the INA. After dismissing the challenge, citing Yakus, ${ }^{72}$ the opinion then declares that "Congress' authority to delegate portions of its power to administrative agencies provides no support for the argument that Congress can constitutionally control administration of the laws by way of a congressional veto." 33 Burger's objection to the veto is not that it fails to meet the procedural requirements of Article I but that it permits Congress to meddle in the work of administrative agencies.

Chadha is comprehensible-and defensible-only as a vindication of the consolidation principle. ${ }^{74}$ The legislative veto is offensive not because it permits centralization but because it interferes with centralization. In violation of the consolidation principle, the veto makes every exercise of governmental power contingent upon interbranch agreement.

\section{B. The Gramm-Rudman-Hollings Case}

While Chadha demonstrates the Supreme Court's endorsement of the consolidation principle, Bowsher $v$. Synar ${ }^{75}$ shows that the principle of separation continues to play an important role in the Court's jurisprudence. In Bowsher, the Court invalidated portions of the Balanced Budget and Emergency Deficit Control Act of $1985,{ }^{76}$ popularly known as Gramm-Rudman-Hollings. This Act authorized the Comptroller General to direct Federal spending reductions in the event that the annual budget passed by Congress failed to meet specified deficit targets.

The Court held that Gramm-Rudman-Hollings gave the Comptroller

legislative veto provision will centralize power that ought to be divided; in such cases, courts should strike down the entire statute. Cf. Note, Resolving Challenges to Statutes Containing Unconstitutional Legislative Veto Provisions, 85 Colum. L. Rev. 1808, 1820-31 (1985) (severability issue should be resolved according to importance to Congress of power involved). Two courts of appeals, in cases involving ultimate power, have diverged from the general rule and invalidated statutes rather than leaving in place broad delegations of authority to the executive. City of New Haven, Conn. v. United States, 809 F.2d 900 (D.C. Cir. 1987) (invalidating statute giving President broad power to revise budgetary allocations by impounding funds); EEOC v. CBS, Inc., 743 F.2d 969 (2d Cir. 1984) (invalidating statute delegating to President power to reorganize agencies). But see Muller Optical Co. v. EEOC, 743 F.2d 380 (6th Cir. 1984) (upholding change in agency structure pursuant to Reorganization Act without considering severability issue).

72. Chadha, 462 U.S. at 953 n.16.

73. Id. at 954 n.16. The connection Burger draws between delegation and administration mirrors the relationship between the demise of the nondelegation doctrine and the birth of the consolidation principle: The New Deal eliminated one set of constitutional constraints on Federal Government structure (nondelegation) but it replaced the obsolete doctrine with a new set of structural requirements incorporating the idea of consolidation.

74. Readers who find my reading of Chadha in tension with what they consider to be Chief Justice Burger's ideological predispositions should note that the majority opinion was joined by Justices Blackmun, Brennan, Marshall, O'Connor, and Stevens.

75. 478 U.S. 714 (1986).

76. Pub. L. No. $99-177,99$ Stat. 1038, 1063-93 (current version codified at 2 U.S.C. $\$ \$ 901-909$ (1988)). 
General, an officer of Congress, powers analogous to an unconstitutional legislative veto: unilateral lawmaking by Congress without bicameral passage or presentment to the President. Chief Justice Burger's majority opinion begins by citing Chadha for the proposition that Congress may not perform executive duties: "To permit an officer controlled by Congress to execute the laws would be, in essence, to permit a congressional veto."77 The rest of the opinion establishes the two premises for a violation under this proposition: that the power to order budget cuts is an executive responsibility ${ }^{78}$ and that the Comptroller General is in fact controlled by Congress. ${ }^{79}$

The latter claim has been hotly disputed both by academics ${ }^{80}$ and by the other Justices writing opinions in Bowsher. ${ }^{81}$ Burger's assertion that the Comptroller General is a congressional agent is founded entirely on Congress' ability, by joint resolution (which must be signed by the President), to remove him for cause. Burger makes no inquiry into the actual relationship between the Comptroller General and members of Congress. In light of the tenuous (arguably nonexistent) control Congress has over the Comptroller General, Justice Blackmun is justified in questioning the

77. 478 U.S. at 726 . Incidentally, this quotation provides further support for the reading of Chadha advanced earlier. See supra text accompanying notes 60-74. The Bowsher Court's restatement of the Chadha holding makes clear that the Court-in retrospect, at least-found the legislative veto offensive due to the power it gave Congress over the administrative agencies.

78. Bowsher, 478 U.S. at 732-33.

79. Id. at 727 .

80. See Elliott, Regulating the Deficit After Bowsher v. Synar, 4 YALE J. ON REg. 317, 323 (1987); Levinson, Balancing Acts: Bowsher v. Synar, Gramm-Rudman-Hollings and Bejond, 72 CoRneli. L. REv. 527, 535-37 (1987).

81. See Bowsher, 478 U.S. at 739 (Stevens, J., concurring in judgment); id. at 777 (Blackmun, J., dissenting); id. at 770-75 (White, J., dissenting) (Comptroller General is "one of the most independent officers in the entire federal establishment ... . [Congress' alleged control is] wholly chimerical.").

Burger's characterization of the Comptroller General's responsibilities under Gramm-RudmanHollings as executive is equally subject to attack. The majority opinion states: "Interpreting a law . . . to implement the legislative mandate is the very essence of 'execution' of the law. Under [the Act] the Comptroller General must exercise judgment concerning facts that affect the application of the Act." Id. at 732-33. But as Professor Elliott notes, this definition is "utterly vapid and without content." Elliott, supra note 80 , at 326 . Interpretation of the law and judgment concerning facts would seem, if anything, to be hallmarks of the adjudicative function rather than the executive.

Burger's choice is especially interesting because classifying the Comptroller General's budgetary powers as legislative rather than executive would have disposed of the case immediately. Given that the Comptroller General is considered to be an agent of Congress, a delegation of legislative authority would present a case identical to Chadha.

The Court could easily have taken this course. The powers given to the Comptroller General are just as "legislative" as the Chadha veto, if not more so. The budget cuts mandated by the Comptroller General replace resolutions that would otherwise need to be passed by Congress. Further, budgeting, unlike immigration policy, begins and ends with the legislative process; it has no administrative component. The Court's choice to call the Comptroller General's powers "executive" signals a crucial difference between the analytic underpinnings of Chadha and Bowsher: Chadha involved operational power, and therefore applied the consolidation principle; Bowsher involved ultimate power, triggering the separation principle. The rhetoric of the two cases, however, is precisely backwards. With the legislative veto, Congress improperly involved itself in administration, notwithstanding the Chadha opinion's emphasis on defining "legislation." In Bowsher, though the opinion devotes its analysis to defining the executive function, the power at stake is much closer to legislation. 
"sense of invalidating legislation of this magnitude in order to preserve a cumbersome, 65-year-old removal power that has never been exercised and appears to have been all but forgotten until this litigation."82

The answer to Justice Blackmun's question is that Gramm-RudmanHollings' delegation of budgeting authority was unconstitutional whether the Comptroller General is considered to be an agent of Congress or an agent of the President, or even the head of an administrative agency (the General Accounting Office). In contrast to Chadha, Bowsher concerns ultimate power. Unlike the deportation power, which is a direct exercise of policy-making authority over the clients of an administrative agency, the budget acts on administrative agencies; it decides what areas of society the government will regulate, and sets priorities among these areas. Consequently, exercise of the budget power is governed by the separation principle.

Unlike the consolidation principle, which demands centralization, the separation principle requires that power be shared among the branches. Neither Congress nor the President may exclude the other from budgeting. Further, the budget power may not be delegated to an administrative agency; such delegation would concentrate power just as much as if Congress or the President were to gain complete control. ${ }^{83}$ The status of the Comptroller General, then, was irrelevant to Bowsher's outcome. Centralization of budgeting power doomed Gramm-Rudman-Hollings, rather than the particular allegiance of the officer under whom power was consolidated. While Chadha applied the consolidation principle in the context of an exercise of operational power, Bowsher involved a violation of the separation principle in its sphere of appropriate application-the exercise of ultimate power ${ }^{84}$ (refer again to Figure 1).

82. Id. at 778 (Blackmun, J., dissenting).

83. In this sense, a "neo-nondelegation doctrine" has survived the New Deal as a component of the separation principle: Congress retains a nondelegable share of ultimate power.

84. See also Buckley v. Valeo, 424 U.S. 1 (1976) (per curiam). The Buckley Court declared unconstitutional the structure of the Federal Elections Commission (FEC) because Congress appointed a majority of its voting members. This structure violated the separation principle. The appointment power-a power exercised over agency personnel, not over non-governmental actors-is ultimate power, and the separation principle requires its division. Allowing one branch to control appointment of agency heads would consolidate all governmental power, not just the operational power required for activism.

It might seem that the FEC's commission structure perfectly satisfied separation principle imperatives by giving each branch a voice. But the authority to appoint a majority of the FEC empowered Congress to render the President's contribution nugatory in the event of a conflict between the two branches. The separation principle forbids such an arrogation; each branch must retain a veto over exercises of ultimate power. The Court recognized this dictate by suggesting that the FEC be reformed so that Congress and the President would jointly appoint a majority of its members. Id. at 143.

Recently, the Court again confronted issues of agency control in Mistretta v. United States, $109 \mathrm{~S}$. Ct. 647 (1989). Mistretta upheld the Sentencing Reform Act of 1984, 18 U.S.C. \$ 3551-3580 (Supp. V 1987), 28 U.S.C. \$\$ $991-998$ (Supp. V 1987), which created a Sentencing Commission staffed in part by Federal judges. The Court recognized that the judges staffing the Sentencing Commission will not be acting qua Federal judges, and therefore will not be subject to control by the Supreme Court other than through the ordinary processes of judicial review; consequently, there is no danger that the 
The true doctrinal foundation of the Bowsher decision is reflected in the Court's key statement of Gramm-Rudman-Hollings' flaw: "The executive nature of the Comptroller General's functions under the Act [remember that Burger has previously stated that Gramm-Rudman-Hollings is invalid if it gives the Comptroller General executive responsibilities] is revealed in $\S 252(\mathrm{a})(3)$ which gives the Comptroller General the ultimate authority to determine the budget cuts to be made." ${ }^{385}$ It is this exercise of "ultimate authority" by a single institution that established a constitutional violation.

Note, however, how difficult it was for the Court to arrive at the Bowsher holding. The Court's failure to develop explicitly the two-tiered structure of constitutional restrictions on the Federal Government left no doctrinal tool available to invalidate a delegation to the executive-short of reviving the nondelegation doctrine, which the Court was unwilling to do. This explains why Burger reached so far to classify the Comptroller General as a congressional official: To challenge Gramm-RudmanHollings, the Court was forced to rely on a dubious removal argument.

\section{Applying the Two-Tiered Theory: The Competition in Contracting AcT}

Similar doctrinal contortions will undoubtedly continue to plague the Court as it is presented with difficult cases involving the allocation of power between Congress and the executive branch. For example, Bowsher cast doubt on responsibilities assigned to the Comptroller General in as many as forty-five statutes ${ }^{86}$ including the Competition in Contracting Act (CICA) ${ }^{87}$ which gives the Comptroller General a limited authority over government procurement. The U.S. Court of Appeals for the Ninth Gircuit recently upheld the constitutionality of CICA in Lear Siegler, Inc., Energy Products Division v. Lehman. ${ }^{88}$ As I will show, however, CICA violates the consolidation principle. My discussion of CICA will suggest how courts may usefully apply the two-tiered theory when deciding future cases.

In addition, examining the Ninth Circuit's opinion upholding GICA will illuminate the pitfalls created for lower courts by the disjunction be-

ultimate power of control over the Commission will be concentrated in the Court. See Mistretta, 109 S. Ct. at 665-66 (Commission "is not controlled by or accountable to members of the Judicial Branch. The Commission... [is] "an independent agency, not a court . . ..").

85. Bowsher, 478 U.S. at 733.

86. See Ameron v. United States Army Corps of Eng'rs, 809 F.2d 979, 1002-06 (3d Cir. 1986) (Garth, J., dissenting), cert. granted, 108 S. Ct. 1218, cert. dismissed, 109 S. Ct. 297 (1988).

87. Competition in Contracting Act of 1984, Pub. L. No. 98-369, § 2701, 98 Stat. 1175, 1199 1203 (codified in scattered sections of 31 U.S.C. and 41 U.S.C.; controversial bid protest and stay provisions codified at 31 U.S.C. $\$ \S 3551-3556$ (Supp. V 1987)).

88. 842 F.2d 1102 (9th Cir. 1988), modified by Nos. 86-6496, 87-5698, 87-5670 (9th Cir. July 17, 1989) (LEXIS, Genfed library, 9th file); see also Ameron, 809 F.2d at 988-98 (upholding constitutionality of CICA). 
tween the Supreme Court's rhetoric and the actual two-tiered constitutional framework. The erroneous Lear Siegler decision highlights the need for the Supreme Court openly to confront the New Deal transformation.

\section{A. Factual Background}

Congress enacted CICA in 1984 in an attempt to exercise control over the Federal procurement process. Congress has found Federal agencies, defense agencies in particular, to be persistent in awarding negotiated sole-source contracts ${ }^{89}$ despite Congress' repeated expressions of preference for competitive bidding. ${ }^{90}$ CICA permits disappointed bidders to bring claims of agency noncompliance with competitive bidding procedures to the Comptroller General for review. ${ }^{\text {11 }}$

Although the Comptroller General's recommendations carry no legal force, CICA stays a contract award until the Comptroller General's investigation is complete. ${ }^{92}$ Stays are intended to prevent agencies from circumventing the Comptroller General's intervention by rushing to begin execution of a contract upon the receipt of a bid protest. ${ }^{93}$ The duration of the stay is limited to ninety days, ${ }^{94}$ however, and the agency may override the stay under "urgent and compelling circumstances."

\section{B. The Unconstitutionality of CICA}

The first step in assessing CICA is to note that operational power is at issue. The ability to make procurement decisions is an essential prerequisite for agency independence in policy implementation. By permitting the Comptroller General to manipulate stay duration, GICA allows direct interference with the procurement decisions of executive bureaucrats. This gives Congress the ability to frustrate virtually any agency initiative. ${ }^{98}$

89. S. ReP. No. 50, 98th Cong,, 1st Sess. 7-9 (1983), reprinted in 1984 U.S. Code Cong. \& ADMIN. NEWS 2174, 2179-82.

90. See 10 U.S.C. § 2305 (1988); 41 U.S.C. § 253(a) (1982).

91. 31 U.S.C. $\$ 3552$ (Supp. V 1987).

92. Id. $\$ \S 3553(\mathrm{~b})-3553(\mathrm{c})$.

93. House Comm. on Gov't Operations, The President's Suspension of the Competition in Contracting Act is Unconstitutional, H.R. Rep. No. 138, 99th Cong., 1st Sess. 4-5 (1985).

94. Department of Defense Appropriations Act, Pub. L. No. 100-463, § 8139, 1988 U.S. CoDE Cong. \& ADmin. News (102 Stat.) 2270, $2270-47$ (to be codified at 31 U.S.C. $\$ 3554(a)(1)$ ). This limitation was enacted, according to its sponsor, to remove any "legal cloud over the constitutionality" of CICA. 134 Cong. Rec. S11,542 (daily ed. Aug. 11, 1988) (statement of Sen. Cohen).

95. 31 U.S.C. $\S 3553$ (d)(2) (Supp. V 1987).

96. This assertion relies on two factual premises, neither of which may be empirically supportable. First, it assumes that the Comptroller General is an agent of Congress. But see supra notes 80-82 and accompanying text. Second, it assumes that the Comptroller General's CICA stay powers significantly hamper agency procurement initiatives. But these powers are quite limited. See supra text accompanying notes 94-95. Perhaps the potential interference with agency functions is de minimis, and thus inoffensive. Note, however, that in even a moderately fluid market environment the ability to stay contract execution enables the Comptroller General to prevent agencies from taking advantage of 
Like Chadha's legislative veto, CICA destroys the consolidation of power by subjecting procurement policy to the joint control of Congress and the executive agencies. ${ }^{97}$

The consolidation principle does not eliminate a congressional role in oversight of the agencies. It does, however, forbid Congress from unilateral oversight. Congress is certainly able to direct the Comptroller General to investigate procurement decisions and to make recommendations. But in order to effect these recommendations, Congress must gain the assent of the President. CICA overstepped this limitation by giving the Comptroller General a tool-the stay provisions-with which to force executive assent. Divesting the Comptroller General of the authority to vary stay duration would deprive him of this tool and restore the proper balance between consolidation and separation.

\section{G. The Lear Siegler Opinion}

The Lear Siegler court fails to make this analysis, and the reasons for its error are instructive. The opinion acknowledges that CICA's stay provisions affect procurement, but nonetheless declines to invalidate the law. Lear Siegler interprets Bowsher's "ultimate authority" language to permit Congress to influence administrative agencies as long as it stops short of a total arrogation of power..$^{98}$ Because the Comptroller General's eventual recommendations lack legal force, the court argues that CICA leaves final procurement decisions to executive agencies and that the scope of the Comptroller General's power does not violate the "ultimate authority" standard.

Lear Siegler correctly perceives that a notion of ultimate authority is at the heart of the Bowsher holding. But the court misunderstands the phrase by appreciating only one of its two meanings. First-as Lear Siegler does understand-"ultimate authority" expresses the standard of review employed by the Court in Bowsher: Legislation is unconstitutional if it excludes the President entirely. But-and this is what Lear Siegler misses-this standard is not applicable to every case. Where operational power is at stake, restraints on congressional intermeddling are much stricter; under the consolidation principle, any interference is offensive, even if the President is not completely shut out.

That is the second meaning of "ultimate authority": It describes the sort of policy-making power that implicates the principle of separation

favorable market conditions. This gives the Comptroller General powerful bargaining leverage with which to force agency compliance with congressional procurement objectives.

97. For alternative appraisals of CICA's constitutionality, see Burns \& Markman, supra note 34, at 593-98; Krent, Separating the Strands in Separation of Powers Controversies, 74 VA. L. REv. 1253, 1289-93 (1988); Weitzel, GAO Bid Protest Procedures Under the Competition in Contracting Act: Constitutional Implications After Buckley and Chadha, 34 CATH. U.L. REv. 485 (1985).

98. Lear Siegler, 842 F.2d at 1108 ("critical issue is whether Congress or its agent seeks to control (not merely to 'affect') the execution of its enactments") (emphasis in original). 
rather than consolidation. Bowsher properly applied the "ultimate authority" standard of review because the case involved the ultimate power of budgeting. In contrast, the Comptroller General exercises operational power under GICA. By failing to recognize this distinction, the Lear Siegler court mistakes the type of power at issue in CICA, and it applies a correspondingly mistaken standard of review. Put another way, the appropriate precedent is Chadha, not Bowsher, because CICA, like the legislative veto, allows Congress to interfere directly with the decisions of government bureaucrats (see Figure 2) ${ }^{99}$ The Ninth Circuit's failure to distinguish between the two Supreme Court decisions is not surprising in light of the Court's own confused rhetoric. Lear Siegler stands as a challenge to the Court to set out clearly the conceptual framework underlying its separation of powers holdings.

Figure 2

Case

Chadha, CICA

Bowsher

Lear Siegler
Type of Power at Stake

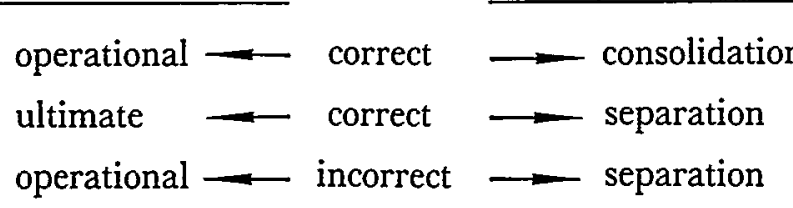

\section{Conclusion: Normative Justifications for the Principle of Consolidation}

Thus far I have endeavored to make two central points. My first claim is that the Court's abandonment of the nondelegation doctrine signalled the New Deal's repudiation of a Federalist conception of separation of powers. Second, I claim that to fill the doctrinal void left by the demise of the nondelegation doctrine, and to give effect to the vision of activist government affirmed by the New Deal, the Court has developed a two-tiered theory demanding both that administrative agencies be sufficiently power-

99. Morrison v. Olson, 108 S. Ct. 2597 (1988), is also interesting in this connection. Morrison upheld the independent counsel provisions of the Ethics in Government Act of 1978, Pub. L. No. 95521, 92 Stat. 1867 (independent counsel provisions codified at 28 U.S.C. $\$ \S 591-599$ (Supp. V 1987)). This Act established a procedure for appointing a special prosecutor to investigate and litigate charges of misconduct by executive branch officials. Some analysts interpreted the special prosecutor as a congressional aggrandizement of power that is properly the executive's. Morrison, however, correctly applies the two-tiered theory in vindicating the Act. The critical fact ignored by the Act's detractors is that the prosecution of official misconduct is an exercise of ultimate, not operational power; the special prosecutor's actions are directed at government officials, not private citizens. Rather than leave such prosecution decisions entirely within the hands of Justice Department officials, the separation principle calls for dispersion of authority among all three branches. The Act accomplishes this with a finely-wrought scheme conditioning prosecution on action by Congress, the Attorney General, and a "special division" of a Federal court. Critics of the Morrison decision make the Lear Siegler error in reverse: Because they mistake Morrison for a case involving operational power, they incorrectly apply the consolidation principle. 
ful to regulate autonomously and that control over the direction and shape of the administrative state be divided between Congress and the President.

Even readers who accept these contentions may nonetheless resist a two-tiered theory on normative grounds. In particular, the consolidation principle is likely to meet opposition based on a Federalist argument that consolidated power spells tyranny: Power must be divided so that the government will be "oblige[d] . . to control itself." 100

But this view is no longer valid; it hinges on an untenable distinction between government action and government inaction. Those who consider the Constitution to guarantee positive rights-the right to freedom from discrimination for example, or the right to education ${ }^{101}$ - will certainly agree that rights can no longer be thought to rest on government inaction (or, at the very least, that rights are no more likely to be vindicated by government inaction than by activism). ${ }^{102}$

Even those who reject a broad reading of constitutional rights must recognize the enduring lesson of the New Deal period that the "natural" system of common law market regulation is not prepolitical. ${ }^{103}$ This recognition renders anachronistic a theory of political rights preferencing government inaction. The two-tiered theory builds on the insight that government action should not be conceptualized as change from some private, prepolitical baseline. Rather, government action should be treated as part of the background.

Because administrative agencies do not change drastically on their own, ${ }^{104}$ however, the political theory I am suggesting is not as dissimilar to the Federalist theory as it may appear. It calls for a revision of the separation of powers, not a rejection of it. In the Federalist view, separated powers enable each branch to veto government action it thinks unconstitutional. The view of the two-tiered theory is somewhat different: Each branch can veto a change in the status quo that it deems unconstitutional. The slow rate of internally-driven agency change gives meaning to the separation principle's check on the exercise of ultimate power. The Federalist bias against action is transformed into a bias against change.

100. The Federalist No. 51, at 322 (J. Madison) (C. Rossiter ed. 1961).

101. See, e.g., Michelman, The Supreme Court, 1968 Term-Foreword: On Protecting the Poor Through the Fourteenth Amendment, 83 HARv. L. REv. 7, 7-19 (1969) (Constitution guarantees "minimum welfare"); Michelman, Welfare Rights in a Constitutional Democracy, 1979 WASH. U.L.Q. 659; of. Currie, Positive and Negative Constitutional Rights, 53 U. CHI. L. REv. 864 (1986) (suggesting that some constitutional rights might be characterized as positive).

102. Professor Mashaw adds justifications for activist agencies based on wealth maximization and on governmental legitimacy. See Mashaw, Prodelegation: Why Administrators Should Make Political Decisions, 1 J.L. ECON. \& ORganization 81, 91-99 (1985).

103. See Erie R.R. Co. v. Tompkins, 304 U.S. 64, 78 (1938) ("IW]hether the law of the State shall be declared by its Legislature in a statute or by its highest court in a decision is not a matter of federal concern.").

104. Political science literature is rife with claims that the pace of bureaucratic change is incremental. See, e.g., H. Kaufman, Are Government Organizations Immortal? (1976); S. Kelman, Making Public Policy 109-10 (1987). 